\title{
INFLUENCE OF PARENTAL PARTICIPATION ON ACADEMIC PERFORMANCE AMONG CHILDREN IN EARLY CHILDHOOD DEVELOPMENT AND EDUCATION CENTRES IN WALDAI ZONE, KERICHO COUNTY, KENYA
}

\author{
Joshua Manduku ${ }^{1, N a n c y ~ C h e r o n o ~}{ }^{2^{*}}$ and Stanley Amdany ${ }^{3^{*}}$ \\ ${ }^{1}$ Senior Lecturer, Dr. University of Kabianga, Kericho, Kenya, mandukujoshua@gmail.com \\ ${ }^{2}$ Mrs, Teacher,Kapsuser Primary School, Kericho, Kenya, rononancy@yahoo,com \\ ${ }^{3} \mathrm{Mr}$, Teacher, Kessup Mixed Day Secondary School, Tambach, Kenya, \\ stanleykimasar@gmail.com \\ ${ }^{*}$ Corresponding Authors
}

\begin{abstract}
Parental participation in young children's education is a fundamental right and obligation. It is a family involvement process that includes the attitudes, values and practices of parents in raising young children.Nurturing warm, and responsive parent-child relationships in Child-centered activities related to positive learning outcomes in early childhood. The purpose of this study was to examine the influence of parental participation on academic performance among children in Early Childhood Development and Education Centres in Waldai Zone,Kericho County, Kenya. The objectives that guided the study included; assessing the influence of parental encouragement of their children to learn at home,on academic performance, investigating the effect of parental guidance on academic performance of ECD children, examining the influence of parental communication with the school, on children's academic performance and establishing the effect of parental support of educational activities on children's performance in school.The theory that underpinned this study was the Structural Functionalism Theory. The theory postulates that the human society is like an organism made up of structures known as social institutions, which are specially structured to perform various functions on behalf of the society. The study adopted a descriptive survey design and was carried out in Waldai zone, Kericho County.Purposive sampling and simple random sampling were used to select participants who comprised of a target population of 155 respondents, 35 headteachers, 70 preschool teachers and 50 parents, to get the sample size of 10 headteachers, 19 preschool teachers and 13 parents. The instruments that were used in collection of data included use of questionnaires, interviews, documents analysis and observations. Descriptive statistics were used to analyze the data.Quantitative data was coded and analysed using the SPSS. Data was analyzed using frequencies and percentages and presented in pie charts, tables and bar graphs. The findings revealed that majority of the parents believed that the responsibility for their preschool children's learning depended on the shared participation between them and the school. The findings also showed that there is a strong correlation between parental monitoring of school work and performance (0.7752). The study concluded that parental participation influences the academic performance among children in ECDE centres and recommends the Ministry of Education to ensure the presence of a functional Partnership between parents and teachers as
\end{abstract}


an important aspect of a child's academic and social achievement. Preschool teachers should be well trained and paid so that they have the ability and time to invite parents' participation and the knowledge to provide parents with clear strategies for rich relationship with their children. This is done through nurturing and having warm parent-child relationship.

Keywords: Parental Participation, Early Childhood Education, Academic Performance

\section{INTRODUCTION}

International Policy documents, such as the OECD stating strong reports (2012) and UNICEF innocent report card 8 , describe participation of parents in young children's education as a fundamental right and obligation. The role of parental participation in the nurturing of a child's education and overall development is one of the core indicators of later achievement. Through parental participation, children get to understand and appreciate the importance of a solid education (Taniesha, 2010). According to Harvard Family Research Project (HFRP, 2006), children whose parents participate actively in their education through various activities in early years, have an advantage.

The early years are important because it is the period during which children acquire the basic skills that serve as the foundation for later learning. Moreover, these years are the time when parents' beliefs about their children's abilities are shaped and when children's own academic self-concepts begin to form (HFRP, 2006).

Educators have frequently pointed out the role of family and home environment in determining school progress and that the earlier in a child's educational process parental participation that can lead to good parental encouragement,guidance,communication,collaborating with the community begins, the more powerful the effects on child's holistic development (Desforges \& Abouchaar, 2003).

In South Africa, parents have been given the mandate through the South African School's Act 84 of 1996 to be involved in their children's education (South African Act, 1996). Section 6.1 of the Act provides that parents should take an active role in their children's schoolwork and make it possible for the children to complete assigned homework.Parents should in terms of Section 6.2 attend meetings that the governing body convenes (Duku, 2006). It is at these meetings that parents have opportunities to understand their roles. Parents are also given opportunities to participate in various portfolios such as serving in school committees. The National Curriculum Statement (NCS) also legislates that parents and wider community have an important role to play in curriculum management.The NCS further identifies the benefits of community and parental involvement to include improved school performance, reduced drop-out rates, a decrease in disciplinary problems and generally, a more positive attitude towards the school (Lemmer, 2007).

Parental participation can increase goodwill and communication and help develop a sense of community within the school (Epstein,2011).Parents must supervise their children at home and outside the school. She strongly supports that when parents pay more attention to their children's schooling, they will become more motivated and students achievement levels will tend to increase.

Parents should participate fully in early childhood development education in order to enhance better performance in their ECDE children's activities and welfare (Harris \& Goodall, 2007). According to Kimengi and Lumallas (2009), responsibility for learning is an aspect of parenting that places emphasis on activities in their home and community that promote learning skills in the young child.Their observation goes hand in hand with Dewey's philosophy that in order to help children learn,the school should be an extension of the home so that experiences gained at home and school are related and continuous.

Henderson and Berla (2011) pointed out that parents attitude towards education and achievement have a powerful impact on children's willingness to achieve. They further commented that parents are the most powerful role models that children have, and the more they are involved in their children's education, the higher their level of achievement.When parents show their interest and commitment to the success of their children they will be more motivated to do their best. However, most parents cannot relate their children's poor performance to their own lack of interest and commitment. The researcher has realized that in most public pre-schools and primary schools, many parents have compartmentalized their lives and do not show 
any interest and commitment in their children's education.

The researcher therefore seeks to study parenting, home-school relationships, and parent's attitude on responsibility for learning outcomes and their influence on children's academic performance in public preschools.

\subsection{Statement of the Problem}

The inception of Free Primary Education (FPE) in the year 2003, was as a result of regional gender disparities which were evident in enrolment, completion, repetition, transition and performance (MOEST,2005).With it coming with free learning and instructional materials from preschool to upper primary, one would expect high academic performance in public primary schools. However, this is not the case, in that,most of the pupils in public primary schools still perform poorly (UNESCO,2007). In regard to previous studies made by researchers, a lot of studies have been done concerning teaching/learning materials, performance, parents' socio-economic issues but little has been done regarding parental involvement in encouraging the children, communicating with the school concerning children's learning, guiding their children, collaborating with the community in offering voluntary services in public pre-schools so as to improve their children's academic performance. Young children benefit from their school years if they entered preschool ready to succeed (Reynolds, 2012). Early childhood programmes alone cannot prepare children for holistic development. This calls for active parental participation to ensure that children do not only get into school, but that they learn once they reach the classroom. The study therefore sought to investigate the influence of parental encouragement, guidance on school activities, communication with the school and collaborating with the community on children's academic performance.

\subsection{Purpose of the Study}

The purpose of this study was to examine the influence of parental participation on academic performance among children in public Early Childhood Education Centres, in Waldai zone,Kericho County in Kenya.

\subsection{Objectives of the Study}

The objectives of this study were to:

i. Assess if parents encourage their children to learn at home and its effects on Academic performance.

ii. Investigate the effect of parental guidance on academic performance of ECD children.

iii. Examine the influence of parental communication with the school on ECD children's academic performance.

iv. Establish the effect of parental participation of educational activities on ECD children's academic performance in school.

\subsection{Research Questions}

The study attempted to answer the following questions:

i. How does parental encouragement to learn at home help to improve ECD children's academic performance?

ii. How does parental guidance affect ECD children's academic performance?

iii. How does parental communication with the school influence children's academic performance?

iv. What effect does parental participation in educational activities have on ECD children's academic performance in school. 
Figure 1.The Conceptual Framework

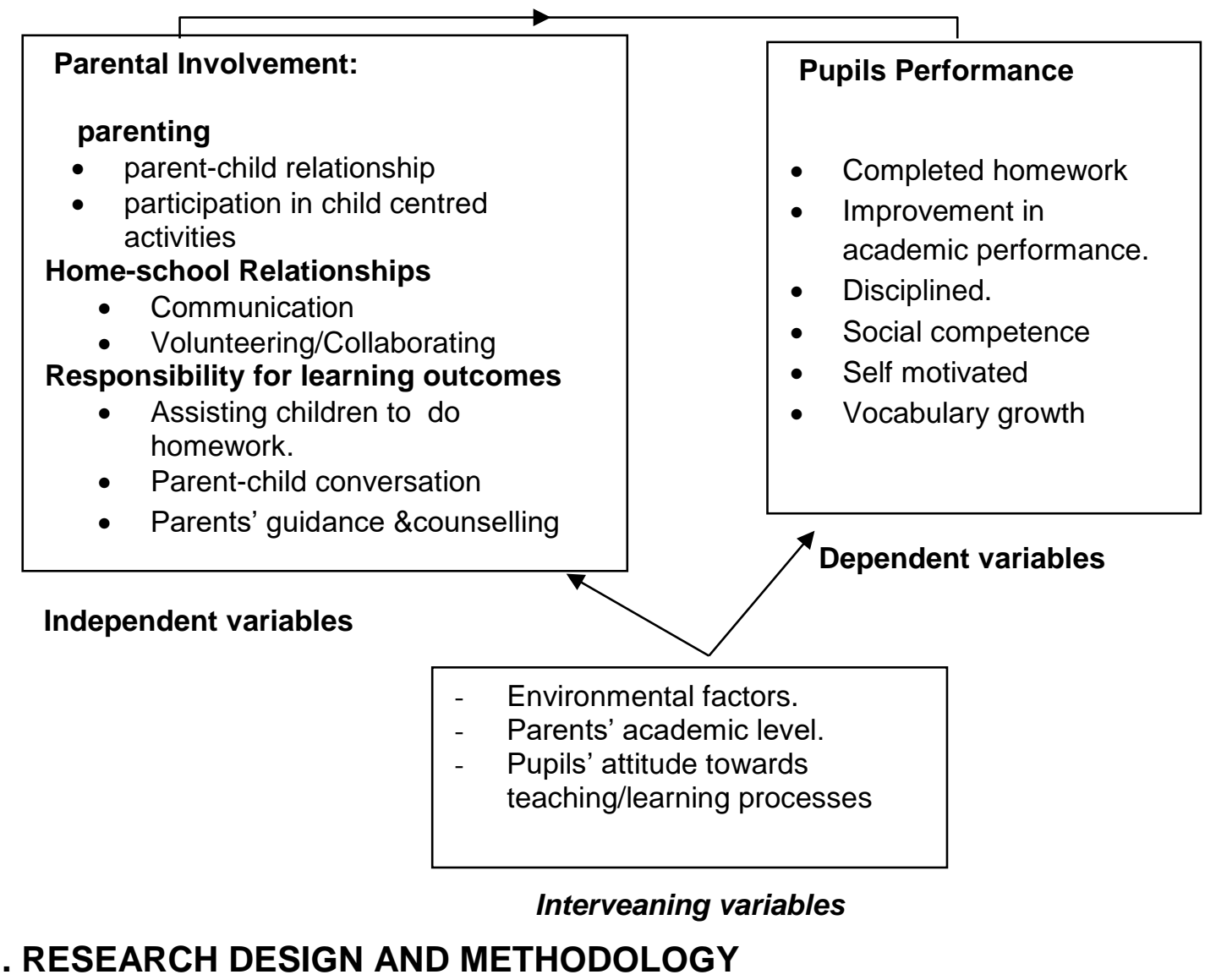

In this study, the researcher adopted a descriptive survey research design and employed a mixed methods research methodology.

\subsection{Location of Study}

The study was carried out in Waldai Zone in Kericho County.Waldai Zone borders Kabianga Zone,Kiptere Zone, Sigowet Zone, Soin Zone and Chaik Zone. It has an estimated population of 12,000 residents. The roads network in the area is good which allowed easy accessibility. The Zone has been chosen because of its practicability and characteristics which are the same as the other Zones in the Sub-county and the whole county of Kericho.Most of the people in the Zone are tea farmers and a few practice dairy farming. As a result of their activities most of them do not have time to guide and counsel their children.

For this study, simple random sampling was used to select sample schools. Parents, head teachers and ECD teachers were selected using purposive sampling from the selected schools (Orodho,2006)

Table 1- Target Population and Sample Size.

\begin{tabular}{|l|l|l|l|}
\hline & Target Population & Sample Population & Sample \% \\
\hline Head teachers & 35 & 11 & $30 \%$ \\
\hline Preschool teachers & 70 & 21 & $30 \%$ \\
\hline Parents & 50 & 15 & $30 \%$ \\
\hline Total & $\mathbf{1 5 5}$ & $\mathbf{4 7}$ & $\mathbf{3 0 \%}$ \\
\hline
\end{tabular}

\subsection{Validity and Reliability of Instruments}

A test retest or coefficient of stability method was used to estimate the degree with a repeated measure of accuracy of the same concept. A correlation coefficient of 0.70 was obtained and was considered reliable (Cohen and Manion,2007). 


\subsection{Data Collection Instruments}

The researcher used Observation checklist, Questionnaires, Document analysis and Interviews to collect data (Kombo and Tromp,2006). The choice of these methods were based on the research design and the nature of research questions. Questionnaires were administered on the parents and headteachers while ECD teacher were interviewed to get the performance of the students. Document analysis was done to get the performance of the students.

\section{DATA ANALYSIS, INTERPRETATION AND DISCUSSION OF FINDINGS}

Table 2. Correlation Between Parental Monitoring and Academic Performance

\begin{tabular}{|c|c|c|c|c|c|}
\hline $\begin{array}{l}\text { No of parents } \\
\text { (n) }\end{array}$ & $\begin{array}{l}\text { Average } \\
\text { attendance }(x)\end{array}$ & $\begin{array}{l}\text { Average pupils } \\
\text { scores (y) }\end{array}$ & $X y$ & $x^{2}$ & $y^{2}$ \\
\hline$A$ & 3 & 50 & 150 & 9 & 2500 \\
\hline B & 3 & 52 & 156 & 9 & 2704 \\
\hline$C$ & 2 & 50 & 100 & 4 & 2500 \\
\hline $\bar{D}$ & 1 & 40 & 40 & 1 & 1600 \\
\hline$E$ & 2 & 50 & 100 & 4 & 2500 \\
\hline $\mathrm{F}$ & 2 & 52 & 104 & 4 & 2704 \\
\hline $\mathrm{G}$ & 4 & 60 & 240 & 16 & 3600 \\
\hline$\overline{\mathrm{H}}$ & 3 & 58 & 174 & 9 & 3364 \\
\hline $\mathrm{I}$ & 2 & 50 & 100 & 4 & 2500 \\
\hline $\mathrm{J}$ & 4 & 70 & 280 & 16 & 4900 \\
\hline $\mathrm{K}$ & 4 & 72 & 288 & 16 & 5184 \\
\hline $\mathrm{L}$ & 4 & 68 & 272 & 16 & 4624 \\
\hline $\mathrm{M}$ & 2 & 56 & 112 & 4 & 3136 \\
\hline$n=13$ & $\sum x=36$ & $\sum y=728$ & $\sum x y=2116$ & $\begin{array}{l}\sum_{112} x^{2}= \\
112\end{array}$ & $\begin{array}{l}\sum y^{2} \\
=41816\end{array}$ \\
\hline
\end{tabular}

$$
\begin{array}{rl}
r=b & x \quad \frac{\sum x y-\left\{\left(\sum x\right)\left(\sum y\right)\right\} / n}{\left(\sum y^{2}\right)-\left\{\left(\sum y\right)^{2} / n\right\}} \\
= & 8.125 \times \quad 2116-\{(36 x 728)\} / 13 \\
& \frac{41816-(529984 / 13)}{} \\
r= & 8.125 \times(0.0954)
\end{array}
$$

The results on Table 2 above shows that there is a strong correlation ( 0.7752 ) between monitoring by parents and the academic performance of pre- school children.This is as per Pearson's Product Moment Correlation Co-efficient which states that a correlation coefficient of above 0.7 shows that there is a strong relationship, while one below it is unreliable (Cohen, et al, 2007).

The $\mathrm{x}$ variable represents the number of times parents monitored their children's homework at school and the $y$ variable represents the average performance of the pupils for three terms. 
Table 3: Involvement in Academic Guidance

\begin{tabular}{|l|c|c|}
\hline & Frequency & Percentage(\%) \\
\hline Involved & 12 & 92.3 \\
\hline Uninvolved & 1 & 7.7 \\
\hline Total & $\mathbf{1 3}$ & $\mathbf{1 0 0 . 0}$ \\
\hline
\end{tabular}

From the research findings shown in Table 3, majority of the parents agreed that they are involved in academic guidance since they want the best for their children. As was observed 12(92.3\%) of them take part in guidance on performance and $1(7.7 \%)$ said that they were not involved.

Naurt (2010) argues that effective parents take nature into account in their nurturing.They should observe,recognize and assess their child's individual genetic characteristics to cultivate their child's strengths and to help them develop in positive ways.

Table 4: Responsibility for Childs Education

\begin{tabular}{|l|c|c|}
\hline Responsibility & Frequency & Percent (\%) \\
\hline Both equally & 9 & 69.2 \\
\hline Wholly/mainly school/Teachers & 4 & 30.8 \\
\hline Total & $\mathbf{1 3}$ & $\mathbf{1 0 0 . 0 0}$ \\
\hline
\end{tabular}

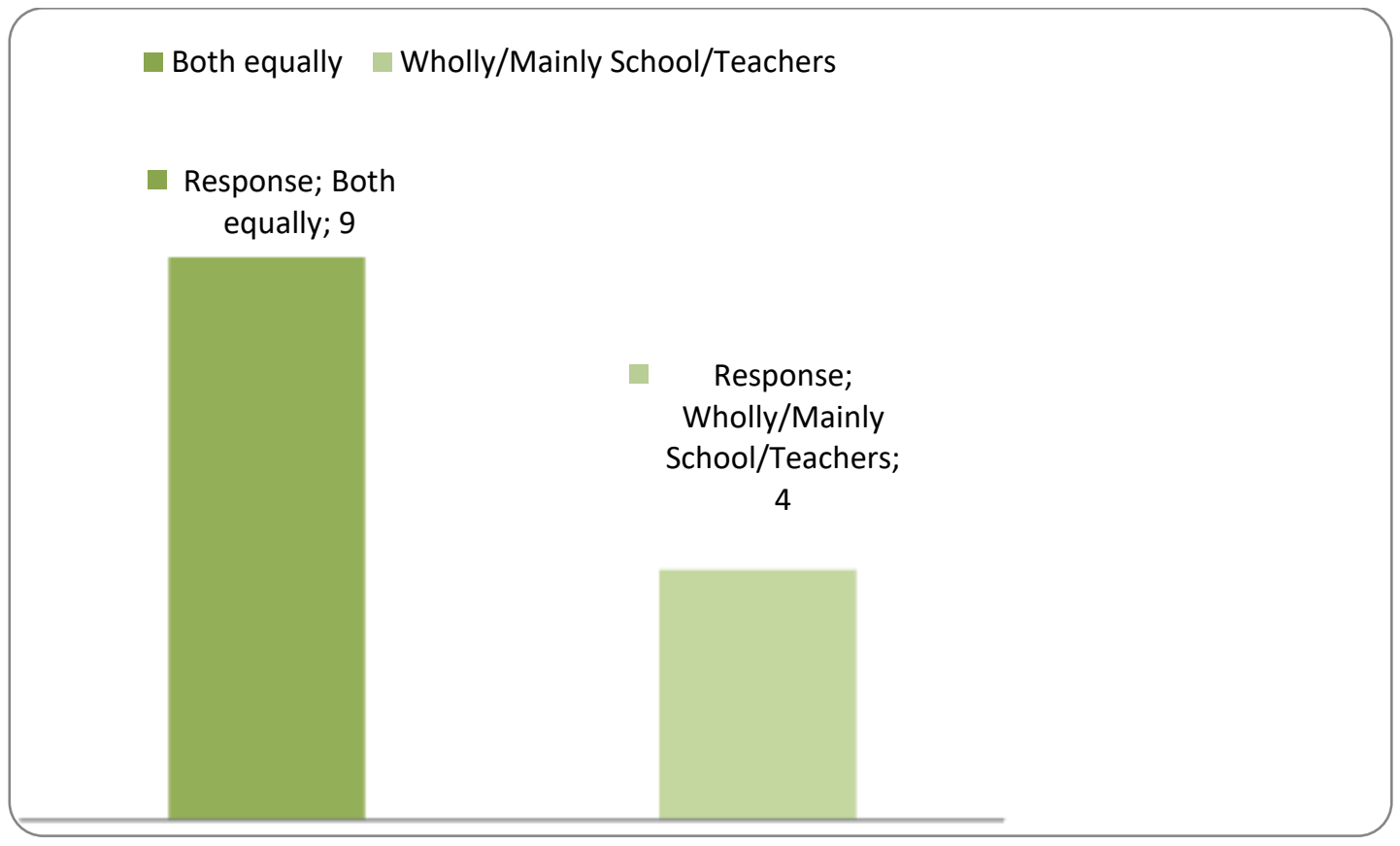

Figure 2. Responsibility for Child's Education

The research results in Table 4 and Figure 2 indicate that Parents believed that the responsibility for the child's education should be equally shared between the parents and the school teachers.

This is seen in their response where 9 (69.2\%) agreed to it, while $4(30.8 \%)$ believed that it should be mainly done by school teachers. The parents did not agree that the child's education is their responsibility alone.

According to Kimengi and Lumallas(2009),responsibility for learning is an aspect of parenting that places emphasis on activities in their home and community that promote learning skills in the young child.Parents 
should participate fully in early childhood development education in order to enhance better performance in children's activities and welfare (Harris \& Goodall, 2007).Furthermore,Reynolds( 2011) argued that young children benefit from their school years if they enter pre-school when ready to succeed. This means that parents have more responsibility in their children's learning than the school-teachers.

Table 5: Communication through School Activity

\begin{tabular}{|l|c|c|}
\hline & Frequency & Percent (\%) \\
\hline Strongly agree & 3 & 23.1 \\
\hline Agree & 10 & 76.9 \\
\hline Total & $\mathbf{1 3}$ & $\mathbf{1 0 0 . 0}$ \\
\hline
\end{tabular}

Source: Researcher (2014).

Establishing a two-way communication between family and the school is associated with performance.From the findings on Table 5,Parents agreed that they ought to communicate with the school in order to participate fully in school activities. This is seen by $10(76.9 \%)$ of the respondents who agreed and $3(23.1 \%)$ who strongly agreed.These findings are in line with Bernard's observations that more frequent parental engagement in school activities contribute to parents' greater knowledge of the school programme and familiarity with the school experiences (Bernard, 2004).

\subsection{Level of Involvement in School Activities}

In the parents' questionnaire an item was included to assess the parents' level of involvement in school activities. The results are presented on Table 6.

Table 6:Level of Involvement in School Activities

\begin{tabular}{|l|c|c|}
\hline Level of involvement & Frequency & Percent (\%) \\
\hline Highly involved & 4 & 30.8 \\
\hline Involved & 8 & 61.5 \\
\hline Completely uninvolved & 1 & 7.7 \\
\hline Total & $\mathbf{1 3}$ & $\mathbf{1 0 0 . 0}$ \\
\hline
\end{tabular}

Source: Researcher(2014).

From the findings , most of the parents think that they are highly involved in school activities. This is evident from the Table 6 where $4(30.8 \%)$,said that they are highly involved,8(61.5\%), said they are just involved, while $1(7.7 \%)$ are completely uninvolved.

Cotton and Wikelund proposed that to foster a good social experience for children, parents should ensure to know what activities their children are involved in. They noted further that involved parents can teach children how to form positive, constructive relationships that do not revolve around harmful behaviors or substances.

Parents should not only look for safety risks from other children but should also know the warning signs of violence within their own children (Cotton and Wikelund, 2011).

\section{SUMMARY}

1. The research findings on Table 4 and Figure 2,indicate that Parents believed that the responsibility for the child's education should be equally shared between the parents and the school teachers. This is seen in their response where $9(69.2 \%)$ agreed to it while $4(30.8 \%)$ believed that it should be mainly done by school teachers. The parents did not agree that the child's education is their responsibility alone.

2. The study found that, majority of the parents agreed that they are involved in academic guidance since they wanted the best for their children. As was observed,12(92.3\%) of them take part in guidance on 
performance and $1(7.7 \%)$ said that they are not involved .Naurt (2010) argued that effective parents take nature into account in their nurturing. They should observe, recognize and assess their child's individual genetic characteristics, to cultivate their child's strengths and to help them develop in positive way.

3. From the findings, Parents agreed that they ought to communicate with the school in order to participate fully in school activities. These findings are in line with Bernard's observations that more frequent parental engagement in school activities contribute to parents' greater knowledge of the school programme and familiarity with the school experiences (Bernard, 2004).

4. The study found out that the parents who get involved very frequently in school activities are very few. This is represented by $1(7.7 \%)$ of the parents. Those involved frequently are represented by $2(15.4 \%)$ those that were undecided about involvement were represented by $1(7.7 \%)$. Most parents were involved partially in their children's school activities. They are shown by $8(61.5 \%)$ and those who do not get involved at all are few as shown by $1(7.7 \%)$. Henderson and Berla (2011), postulated that parents who participate actively in home- school activities have children who do well in school. They observed further that the best activities to be involved in are those which engage the children directly, for example, cooking and cleaning the home with them.

\section{CONCLUSIONS}

1. Based on the findings,the study concluded that parental participation is a vital factor that influences children's performance.Parental encouragement to learn involves assisting with homework,arranging for appropriate study time and space and guidance in various activities to assist in decision making .The concept of parental participation among parents in public pre-schools has not been fully comprehended and therefore has not been utilized fully as it should be.This is evident in the parents' low level of attendance and commitment in the various school activites that call for their participation,since majority of them were involved only when they were called upon.It is also clear that most of the schools in Waldai do not have partnership programmes with their parents (MOEST,2013).This is opposed to what OECD (2006) recommended that Partnership programmes in schools are essential for good performance.

2. The study findings concluded that Parents and pre-school teachers have no unity of purpose in guiding their children towards academic success. The school administration therefore,should introduce parents to their teaching style,discipline methods and classroom policies early in the year through parents' first meeting (orientation).Parents can express their commitment to their children's education by ensuring that children complete their homework assignments promptly.

Parents could also tell the pre-school teachers how much they appreciate their work in school and commend them for their positive attitude towards their children.

Guidance of children as was noted by Naurt (2010),determines the way a child turns out in large part by the day-to-day decisions made by parents who guide that child's growth.

3. Concerning parental communication with the school, the study concludes that to enhance children's performance, a 15-20 minutes of uninterrupted time will establish rapport and develop a common goal or unity of purpose between parents and teachers. This will focus only on helping the pre-school child have the best school experience possible. It also enhances their holistic development and in this case blame games between the teachers and the parents will be avoided (Zarate 2007).

4. Still from the study findings, it is very clear that parents would want to be involved in the various activities that take place in school. The study therefore concludes that the government through the ministry of education should have Parents Empowerment Programmes that will ensure full participation among parents as far as parental participation is concerned, as noted by National Standards for Parents/Family involvement Programmes.From the African philosophy of Socialism,Mutual Social Responsibility should exist between the members of a society in that a society cannot prosper without the full cooperation of its members ( Sessional paper No.10 of 1965).

\section{RECOMMENDATIONS}

Based on the research findings the researcher came up with the following recommendations:

1) The government through the Ministry of Education should organize intervention programmes that will sensitise and empower parents on how to encourage their children in order to enhance their academic performance. Parents should be encouraged to engage in joint school activities with their pre-school children.For example,reading with them,cooking together and washing together.These activities are opportunities to develop cognitive skills. 
2) Standards should be put in place to gurantee that early childhood teachers as well as parents are trained in guidance and counseling skills. This will enable the pre-school teachers have the ability and time to invite parents'participation in the guidance of children .The knowledge will provide parents with clear strategies for rich relationship with their children hence will clarify the specific needs of their children for the teacher to evaluate and diagnose for alearning disability.

3) Concerning communication with school on children's performance,parents should be involved in the disciplinary process of the school.This will involve them ensuring the proper use of time,cases to do with absenteeism,proper uniform,cleanliness and social values among their children. The parents should not leave it simply for the teachers and school administration to enforce discipline.

Bernard (2004) emphasized that parental communication with the school contributes to their knowledge of the school programme and familiarity with the school's experiences.Communication also entails parents teaching their children how to form positive and constructive relationships that do not revolve around harmful behaviours.

4) Concerning voluntary services and collaboration with the community, there should be a functional partnership between parents and teachers as an important aspect of a child's academic and social achievement.Through this parents will be sensitized that while teachers take their professional responsibilities they are recommended to recognize that they cannot do it alone but need and depend on their (parents) support.This will help parents to prioritise the issues they want to address including their children's academic performance.Parents should collaborate and volunteer for supervision services and understanding the school emergency plan so as to keep the Pre- school centres safe.

\section{RERFERENCE LIST}

Barnard, M. (2004). Parent involvement in elementary school and educational attainment. Children and Youth Services Review, 26, 39-62.

Cohen L., Manion L. and Morrison K. (2007). Research Methods in Education. Routledge , New York.

Corpus, J. H., Lepper, M. R. (2007). The Effects of Person Versus Performance Praise on Children's Motivation: Gender and age as moderating factors in Educational psychology, Vol. 27, No. 4, August 2007.

Cotton, K., \& Wikelund, K.R. (2001). Parental involvement in education. Retrieved May 3, 2002, from Northwest Regional Educational Laboratory Web site: http://www.nwrel.org/scpd/sirs/3/cu6.html.

Desforges, C. and Abouchaar, A. (2003). The impact of parental involvement: Parental support and family education on pupil achievement and adjustment: A Literature Review. DFES Research Report.

Duku N. (2006). The exploration of parents' negotiation of their identities in school governance participation in six selected eastern cape communities (unpublished PhD thesis). University of Cape Town.

Epstein, J. L. (2011). School family and community partnerships: preparing educators and improving schools. Second Edition. Boulder, CO: Westview Press.

GOK (2005)Kenya: Consultative group meeting. Joint statement on education, April 2005:(2)

Harris, A. and Goodall, J. (2007). Engaging parents in raising achievement. Do parents know they matter? DCSF RW004.

Henderson, A.T \& Berla N. (2011). A new generation of evidence.the family is critical to student achievement. Erick Digest Clearing House.

Kimengi, I.\& Lumallas, J.(2009). History of education: A study in historical development in educational policies and practices from ancient to modern times. Moi University Press. Lemmer E. M. (2007):

Kombo, D.K. Tromp, D.L. (2006) Proposal and thesis writing: An introduction. ISBN.

MOEST, (2005). The background report of Kenya, report for the UNESCO/OECD Early Childhood Policy Review Project. Nairobi: MOEST.

MOEST, (2013). Belgut Sub County Evaluation results . Kericho

Naurt, R. (2010). Parental Guidance Key Concept in Child Development. Psych Central. Retrieved on 
October 9, 2014, from http://psychcentral.com/news/2010/12/06/parental-involvement-key- for-childdevelopment/21499.html

Orodho, J. (2004). Techniques of writing of research proposal and reports in education and social science. Nairobi: Masola Publishers.

Tanisha, B. (2010) Raising the next Barack Obama: A guide on how to develop core principles for success in your Child. The National Centre for Children in Poverty (NCCP),2013.Columbia University. Mailman School of Public Health Policy and Management.

UNESCO (2007).Education for All Global Monitoring Report:Strong Foundations Early Childhood Care and Education.Retrieved from http://www.unesco.org/new/en/education/themes/leading-the-international agenda/efareport/reports/2007-early childhood.

Zarate,E.(2007). Understanding latino parental involvement; perception, expectations and recommendations. The Tomas Riviera Policy Institute. Los Angeles, CA 